ANNA WIŚNICKA* - LUBLIN

\title{
MIEJSCA KULTU Z BETONU I SZKLA. GENEZA I PRZEGLĄD NAJWAŻNIEJSZYCH TENDENCJI W NOWOCZESNEJ ARCHITEKTURZE SAKRALNEJ PO II WOJNIE ŚWIATOWEJ
}

Koniec wieku XIX stał się początkiem wielkich zmian oraz twórczych poszukiwań nowoczesności. Stopniowa industrializacja i możliwości techniczne stawały się podwaliną nowych teorii i konceptów, które miały ogromny wpływ na sztukę wieku XX. Kluczową rolę w procesie zmiany percepcji architektury w Europie odegrał niemiecki pisarz i projektant Hermann Muthesius. Przebywał on wiele lat w Londynie badając tamtejsze osiągnięcia w dziedzinie budownictwa. Owocem tego pobytu było dzieło, które stało się początkiem zmian w postrzeganiu architektury w Europie kontynentalnej - Das Englische Haus ${ }^{1}$. Ukazano w tej pozycji idee nowej sztuki i podejścia do sztuki, które z czasem zaczęły być coraz bardziej popularne w całej Europie.

Nowoczesne podejście do architektury narodziło się w Holandii. Tam właśnie w latach 1917-1931 działała grupa de Stij12², która niejako zapoczątkowała modernizm w Europie. Propagowana przez nich architektura stanowiła kontynuację postulatów neoplastycyzmu (nieuwe beelding) głoszonych przez Pieta Mondriana oraz zaczątków teorii konstruktywistycznych, łącząc tym samym dwie najważniejsze teorie sztuki po I wojnie światowej. Ich głównym celem, który można odwołać do architektury, było stworzenie języka sztuki, który stawia uniwersalność ponad indywidualność twórczą jednostki. Uproszczono więc formę posługując się kątami prostymi, przewagą poziomu nad pionem. Architektura na powrót uzyskała ludzkie proporcje, stając się bardziej przyjazną człowiekowi, odsunięto

\footnotetext{
* Anna Wiśnicka - mgr historii sztuki, doktorantka w Instytucie Historii Sztuki KUL.

${ }^{1}$ H. Muthesius, Das Englische Haus, Berlin 1904-1905.

${ }^{2}$ Michael White, De Stijl and Duch modernism, Manchester 2003.
} 
się od monumentalizmu na rzecz funkcjonalizmu. Kolorystyka ściśle korespondowała $\mathrm{z}$ teorią Mondriana - na tle ogromnych płaszczyzn bieli używano barw podstawowych, które podkreślały proste, zgeometryzowane kształty budowli.

Pomimo, iż grupa de Stijl nigdy nie podjęła się projektowania budowli sakralnych, wprowadzone przez jej członków zmiany w architekturze ${ }^{3}$ stały się początkiem nowego okresu w dziejach budownictwa. Postulaty modernizmu rozwinęła najpełniej działająca w latach 1919-1933 niemiecka grupa Bauhaus, której dokonania stanowią swoistą cezurę czasową wyznaczającą wiek nowoczesności ${ }^{4}$. Dokonania Ludwiga Miesa van der Rohe oraz Waltera Gropiusa na polu architektury byłynajbardziej wpływowymi tendencjamiXX wieku. Budynkizbetonu, stalii szkła materializowały wizję przestrzeni doskonałej, gdzie świat wewnętrzny i zewnętrzny płynnie się przenikają. Można więc mówić o całkowitym novum, które już niebawem stać się miało udziałem architektury sakralnej. Potrzeba było czasu, by tak odważne formy, przeciwstawiające się poniekąd wielowiekowej tradycji i gloryfikowanej spuściźnie kultury europejskiej, stały się powszechnie akceptowane. Trudno było zrozumieć, że redukcja formy jest naturalnym dążeniem do ładu i porządku a nie chęcią całkowitego odcięcia się od przeszłości.

Wśród realizacji Bauhausu na polu architektury sakralnej przytoczyć można zaledwie jedno dzieło, które oddaje ducha modernizmu. Jest to tzw. Robert F. Carr Memorial Chapel of Saint Savior, kaplica wybudowana w Chicago w 1952 roku jako część kampusu Illinois Institute of Technology, według projektu Ludwiga Miesa van der Rohe ${ }^{5}$. Budynek ma formę prostopadłościanu wykonanego z jasnej cegły. Jego główną ozdobą są okna doświetlające wnętrze - trzy ogromne tafle szkła na górze i na dole przedzielone rzędem sześciu małych okien, umieszczone są od frontu budynku, analogiczny zestaw doświetla tył budowli, zastępując klasyczne prezbiterium. W jego miejscu zawieszono jasną kotarę, na jej tle prezentowany jest krzyż, który oświetlony z obu stron zdaje się unosić w przestrzeni. Sklepienie zdobi drewniany strop o prostej konstrukcji z prostopadle ułożonych desek. Wnętrze pozbawione jest ozdób, pozwala więc na niczym niezmąconą kontemplację. Takie było właśnie założenie, aby usunąć z wnętrza sakralnego wszystkie elementy zbędne, które mogłyby odwrócić uwagę wiernych od tego, co najistotniejsze, a więc modlitwy. Carr Chapel jest przykładem architektury modernistycznej. Tu jednak wymiar praktyczny zmienił się w metafizyczny. Stworzenie otwartych, pustych przestrzeni nie było podyktowane bowiem względami użytkowymi a raczej duchowymi, by ukazać świętość za pomocą środków nowej sztuki. Mies van der Rohe wypowiadał się w 1960 roku na temat swojej architektury w następujący sposób: „Przez całe moje życie myślałem o architekturze, cały czas zastanawiałem się czym jest i jaka może być w naszych czasach. Myślę, że prosta

${ }^{3}$ Członkowie grupy de Stijl prezentowali swoje postulaty stylowe na łamach pisma ,de Stijl”. Por. J. J. P. Oud, Bouwkunst en normalisatie bij den massabouw, „de Stijl”, 7 (1918), Delft, s. 77; Robert van 't Hoff, Architectuur en haar ontwikkeling, ,de Stijl”, 4 (1919), Leiden, s. 40-42.

${ }^{4}$ Podobny punkt widzenia nowoczesności ukazywała wystawa w berlińskiej Nowej Galerii Narodowej pt. „Moderne Zeiten” z roku 2010.

${ }^{5}$ Franz Schulze, The Mies Van Der Rohe Archive: Robert F. Carr Memorial Chapel of Saint Savior, S. R. Crown Hall, \& Other Buildings \& Projects, New York 1992, p. 102-198. 
struktura jest wielką pomocą dla architektury. Teraz jestem stary i nie mogę zrobić nic, co nie jest jasno sformułowane. Dla mnie struktura jest tym samym co logika. Jest najlepszym sposobem tworzenia i wyrażania"

Realizacja dzięki swej prostocie a jednocześnie niezwykłemu wyrafinowaniu znalazła wielu naśladowców. Niewątpliwe podobieństwo z dziełem van der Rohe wykazuje kościół akademicki Uniwersytetu Kardynała Stefana Wyszyńskiego, stojący w centrum kampusu przy ul. Wóycickiego w Warszawie. Pomimo różnic formalnych (dwuspadowy dach, mniejsze powierzchnie przeszklone), budynek wykonany z jasnej cegły, ustawiony w centrum kampusu zdaje się być reminiscencją ideałów twórczych Miesa van der Rohe.

Jeszcze dalej w procesie uproszczenia wnętrza i redukcji formy posunął się japoński architekt Tadao Ando. Jego projekty cechuje puryzm, konsekwencja i dążenie do skrajnego minimalizmu. Łączy z swych pracach orientalną oszczędność formalną z klasycznymi materiałami Zachodu. Szczególnie upodobał sobie beton ze względu na jego chłodną barwę i możliwości dowolnego kształtowania struktury. Ze zbrojonego betonu wykonany jest tzw. Kościół Światła (Church of Light) ${ }^{7}$ z 1988 roku usytuowany w Ibaraki na przedmieściach Osaki. Świątynię najprościej można opisać jako mały, betonowy kubik o powierzchni niespełna 115 metrów kwadratowych, którego boczne ściany załamują się w połowie pod kątem 15 stopni. O charakterze miejsca nie decydują jednak jego wymiary a niezwykły zabieg stylistyczny zastosowany przez architekta. Polega on na wycięciu we wschodniej ścianie kościoła kształtu prostego krzyża greckiego. Kościół jest orientowany, więc wspomniana ściana znajduje się tuż za ołtarzem, będąc każdego ranka przepełniona promieniami słonecznymi. Krzyż oświetla ciemną, pustą przestrzeń kościoła, symbolizując słowa Jezusa z Ewangelii św. Jana Ja jestem świattościa świata. Kto idzie za Mna, nie będzie chodził w ciemności, lecz będzie miat światto życia $(\mathrm{J} 8,12)$. Kościół światła jest przykładem na to, jak kultura orientalna i wzrastający w niej architekt może interpretować miejsce kultu i modlitwy. Jest to budynek na wskroś nowoczesny, w którym w sposób bardzo subtelny zaakcentowano tradycyjne pojmowanie wiary. Niespotykane dotychczas zderzenie dwóch zupełnie odmiennych kultur zaowocowało stworzeniem kościoła o niepowtarzalnym wyglądzie i charakterze, którego językiem wyrazu jest cisza ${ }^{8}$.

Nowoczesna architektura sakralna nie ogranicza się jedynie do prostych, geometrycznych form, o czym przekonał świat w 1954 roku francuski architekt Le Corbusier9. Jego niezwykłe dzieło Chapelle Notre-Dame-du-Haut de Ronchamp zwane często Ronchamp ${ }^{10}$ to kaplica pielgrzymkowa usytuowana $\mathrm{w}$ górach $\mathrm{w}$ regionie Franche-Comté. Założeniem architekta było stworzenie dzieła nowoczesnego, które jednocześnie odwoływać się będzie to pierwotnych, prymitywnych cech architektury. Połączenie ze sobą tak skrajnych postulatów wymagało dużego

${ }^{6}$ Conversations with Mies van der Rohe, ed. Moisés Puente, Princeton 2008, p. 31 [thum. fragmentu A. Wiśnicka].

${ }^{7}$ M. Furuyama, Ando, New York 2008.

${ }^{8}$ W. Blaser, Tadao Ando. Architecture of silence, Basel 2001.

${ }^{9}$ Wł. Charles-Édouard Jeanneret-Gris.

${ }^{10}$ E. Stoller, The Chapel at Ronchamp, Princeton 1999. 
doświadczenia, które Le Corbusier wówczas posiadał. Budynek wykonany z żelbetu ma organiczną formę złożoną z ustawionych pod różnym kątem ścian oraz ogromnego dachu, przypominającego żagiel na wietrze. Jest to czytelna analogia do przedstawień kościoła jako łodzi ${ }^{11}$. Taka symbolika przywodzi na myśl zarówno Arkę Noego (Rdz 6, 14 - 8, 19), jak i ewangeliczną barkę Piotra i Andrzeja (J $1,44)$.

Wnętrze, podobnie jak to miało miejsce w wielu budowlach tego okresu, jest prawie puste. Jedynymi meblami są skromne ławki dla wiernych oraz ołtarz. Dramaturgii wnętrzu nadają małe, nieregularnie rozmieszczone we wszystkich ścianach i głęboko osadzone okna, niektóre wypełnione kolorowym witrażowym szkłem. Jako kaplica pielgrzymkowa Ronchamp posiada również zewnętrzny ołtarz usytuowany pod ogromnym dachem, dzięki czemu w nabożeństwie może uczestniczyć duża liczba osób. Swobodny przepływ wiernych zapewniają dwa wejścia do budynku. Kaplica Le Corbusiera jest przykładem nowoczesnej architektury, która prezentuje zupełnie nową, nieznaną dotąd jakość. Jej bryła dominuje nad krajobrazem a jednocześnie się w niego wtapia. Jest to budowla pełna ekspresji, której wnętrze przepełnia spokój. Ten swoisty dualizm wrażeń jest prawdopodobnie efektem celowym. Niemożność zaklasyfikowania kaplicy Ronchamp do żadnego stylu w architekturze świadczy o jej unikatowości i geniuszu projektanta.

Innym architektem, który wypracował swój własny, niepowtarzalny styl był fiński modernista Alvar Aalto ${ }^{12}$. W jego dziełach płynnie przeplatają się echa minimalizmu i modernizmu, połączone z szacunkiem do fińskiej natury i tradycji. Aalto zaprojektował w 1978 roku kościół Santa Maria Assunta dla włoskiej miejscowości Riola położonej na Sardynii. Motywem przewodnim projektu jest słynna falista linia, którą Aalto uczynił swoim znakiem rozpoznawczym. Kościół ma formę nieregularnej bazyliki, przekrytej uskokowym falistym dachem o czterech poziomach, spływającym coraz niżej z lewej na prawą stronę budowli. Kontrast dla dachu stanowią gładkie ściany. Fasada przypomina łuk, którego górna część podzielona jest czterema wycięciami. Wejście do świątyni ma kształt ogromnego, poziomego prostokąta kontrastującego z organicznym kształtem fasady. Przed kościołem ustawiono nowoczesną kampanilę. Zarówno kościół jak i dzwonnica wykonane są w betonu i kamienia, dach świątyni pokryto natomiast miedzianą okładziną.

Największe wrażenie w projekcie Aalto robi jednak wnętrze kościoła. Jest bardzo jasne, przestronne i białe. Umieszczone wysoko w dachu okna doświetlają przestrzeń. Stopniowa gradacja natężenia naturalnego sprawia, że prezbiterium wyłania się z mroku, jest najjaśniejszą częścią w kościele, co poza wymiarem estetycznym wydaje się mieć również wymiar symboliczny. Strop unoszą ogromne belki o falistym kształcie, które dominują we wnętrzu. Na ścianie prezbiterialnej zawieszono tylko prosty krzyż.

Kościół Aalto jest dziełem przełomowym. Po pierwsze ze względu na sam

${ }^{11}$ Stanisław Groń SJ, Łódź Symbolem Kościoła Chrystusowego, w: www.jezuici.pl/am/arc/arc 055.htm, stan z dn. 20.11.2010.

${ }^{12}$ L. Lahti, Alvar Aalto, New York 2009. 
projekt, bardzo nowoczesny, specyficzny, niepowtarzalny. Po drugie należy zwrócić uwagę na fakt, iż kościół Santa Maria Assunta wybudowano we Włoszech, gdzie tradycje chrześcijańskie są niezwykle silne podobnie jak przyzwyczajenia w dziedzinie budownictwa sakralnego. Budowla Alvara Aalto jest więc dowodem na to, że modernizm stał się czymś więcej niż chwilową modą i na stałe wpisał się do historii nowoczesnej architektury.

Nowoczesna architektura w tradycyjnych Włoszech wymagała wiele odwagi. Czy więc cokolwiek mogło krępować formalnie architekta, który sam projektował od zera całe miasto wraz ze świątynią? Na pewno mógł pozwolić sobie na spełnienie swych artystycznych wizji i ambicji, tworząc tym samym przełomowe dzieło. Architektem tym był budowniczy miasta Brazylii - Oscar Niemeyer, który tworzył nową stolicę dla swych rodaków. Jej główny kościół - katedra pod wezwaniem Matki Bożej z Aparecidy ${ }^{13}$ powstawała przez prawie dwadzieścia lat, konsekracja miała miejsce w 1970 roku. Jest to budowla na wskroś nowoczesna, która dzięki zdobyczom techniki mogła przyjąć kształt korony cierniowej.

Katedra ustawiona jest na okrągłej, betonowej podstawie o średnicy siedemdziesięciu metrów. Wyrasta z niej szesnaście przypór, które łączą się po środku sklepienia, a następnie rozwidlają, tworząc kształt korony z której wyrasta ogromny krzyż. Przestrzeń między przyporami wypełniają witraże w kolorze niebieskim, symbolizujące niebo, które napełniają przestrzeń błękitnym światłem. Nad sklepieniem rozwieszono figury aniołów wykonane z aluminium przez Alfredo Ceschiattiego, które unoszą się lekko w przestrzeni katedry. Wnętrze świątyni jest jasne, uwagę przyciągają zawieszone posągi, które są jedyną dekoracja wnętrza, oraz prosty krzyż ustawiony w prezbiterium. Wokół świątyni ustawione są figury dwunastu apostołów projektu Niemeyera.

Katedra w Brazylii jest budowlą unikatową na gruncie architektury sakralnej. Jej rozmieszczenie na planie koła jest rzeczą bardzo rzadko spotykaną, która do dziś budzi wiele wątpliwości, biorąc pod uwagę skalę budowli. Jest to dzieło, które już samą swoją formą odwołuje się bezpośrednio do Chrystusa. Nadanie kościołowi kształtu symbolu męki Pańskiej świadczy o ogromnej wyobraźni artysty a także o powstawaniu nowej tendencji architektonicznej, która być może będzie częściej stosowana przez architektów na całym świecie.

Aby ukazać jak największą różnorodność tendencji w nowoczesnym budownictwie sakralnym należy również wspomnieć kościół, który bardziej przypomina ogromną rzeźbę plenerową niż miejsce kultu. Chodzi o tzw. Wotrubakirche - kościół św. Trójcy ${ }^{14}$ znajdujący się w wiedeńskiej dzielnicy Mauer, który swą nazwę zawdzięcza projektantowi - Fritzowi Wotrubie. Inicjatorką powstania budowli była austriacka działaczka Margarethe Ottillinger, która wpadła na pomysł zatrudnienia przy projekcie Fritza Wotruby, który pod koniec działalności artystycznej skłaniał się ku sztuce sakralnej. Pierwotnie budynek miał stanąć w górskiej miejscowości Traunstein, jednak lokalni mieszkańcy, wierni tradycji, nie wyrazili na to zgody. Ostatecznie Wotrubakirche wybudowano w Wiedniu, konsekracja miała miejsce w 1976 roku.

\footnotetext{
${ }^{13}$ A. Benthues, 100 katedr świata, thum. M. Chomiuk, Warszawa 2003, s. 196-197.

${ }^{14}$ R. Feuchtmüller, Wotruba: die Kirche in Wien-Mauer, Wien 1977.
} 
Kościół ma kubistyczną formę, na którą składają się sto pięćdziesiąt dwa nieregularnie ułożone ogromne bloki betonu. Między betonowymi bryłami wstawione zostały tafle szkła. Budynek z każdej strony wygląda inaczej, bloki pną się coraz wyżej ku górze. Wnętrze kościoła pozbawione jest ozdób. Najbardziej widocznym elementem jest dużych rozmiarów ołtarz o prostej formie wykonany z marmoryzowanego kamienia. Na centralnej ścianie zawieszono krucyfiks autorstwa Wotruby, wykonany z brązu. Wotrubakirche przywodzi na myśl kamienne kręgi, chociażby słynny Stonehenge, ma jednak bardzo ekspresyjny kształt, który zdaje się być w ciągłym ruchu. Kościół pełen jest wewnętrznych napięć i kontrastów, gry światła i cienia, co najlepiej uwidacznia się w jego wnętrzu. Jest to po dziś dzień najnowocześniejszy i najbardziej ekstrawagancki kościół w kraju świątyni Karola Boromeusza.

Jednym z najbardziej innowacyjnych rozwiązań w dziedzinie budownictwa sakralnego jest projekt kościoła Chrystusa - Światła w Oakland w Kalifornii ${ }^{15}$. Jest to pierwsza katedra XXI wieku. Świadczy o tym nie tylko data konsekracji - 2008 roku. Budynek, według spekulacji najdroższy kościół świata, powstał zgodnie z najnowszymi możliwościami w dziedzinie budownictwa. Przy jego budowie zastosowano ekologiczne rozwiązania, które znane są pod nazwą sustainable design and architecture. Jego projektantem jest architekt Craig W. Hartman współpracujący z firma Skidmore, Owings and Merrill LLP. Kościół przywodzący swą formą na myśl mitrę biskupią wykonano ze stali, szkła i fryty szklanej. Budowla ogromnych rozmiarów w kształcie ściętego stożka na planie elipsy jest całkowicie przeszklona, pełna lekkości i światła. Jej centralny punkt stanowią dwa przecinające się okręgi nad wejściem, tworzące kształt vesica piscis, mający odnosić się do ryby - jasnego symbolu chrześcijaństwa.

Mimozastosowaniudużychilości betonu wnętrzekatedryjestjasne, ciepłeiprzestronne. Głównym źródłem światła jest przeszklony sufit. Ołtarz ustawiono na okrągłym postumencie, ławki dla wiernych rozmieszczone są wokół prezbiterium. Meble wykonano z jasnego drewna, podobnie jak gigantyczne żaluzje na szklanych ścianach.

Kościół Chrystusa - Światła jest w swej koncepcji bardzo nowatorski, łączy bowiem świątynię z kompleksem pomieszczeń towarzyszących. Należą do niego: kancelaria kurii biskupiej, diecezjalne centrum konferencyjne, probostwo, centrum pomocy medycznej dla osób niemających ubezpieczenia zdrowotnego, sklepik z pamiątkami oraz mauzoleum. Kalifornijska świątynia jest więc nie tylko domem modlitwy ale spełnia również funkcje charytatywne, będąc miejscem pomocy ubogim. Jednocześnie ogromne środki jakie pochłonęła budowa obiektu przeszło sto siedemdziesiąt milionów dolarów - budzą wiele kontrowersji. Mimo sceptycyzmu krytyków kościół Chrystusa - Światła jest jedną z najciekawszych realizacji na gruncie architektury sakralnej XXI wieku.

Pozostaje na końcu dodać, iż nowoczesna architektura to nie jedyny model zmian wizualnych w kościele. Fascynacja nowoczesnym wzornictwem i jego piękną formą znajduje swoje odzwierciedlenie w urządzaniu wnętrz sakralnych.

\footnotetext{
${ }^{15}$ www.ctlcathedral.org/, stan z dnia 22.11.2010.
} 
Nie są to bynajmniej kościoły na wskroś nowoczesne, ale historycznie zakorzenione w tradycji. Przykładem może być wnętrze kościoła św. Bartłomieja w czeskich Chodovicach ${ }^{16}$, którego historia sięga roku 1384. Obecnie jego wiekowe wnętrze zmodernizował w 2010 roku architekt Maxim Velcovsky należący do grupy Qubus Studio. Tradycyjne ławy kościelne zastąpiły słynne krzesła S projektu Vernera Pantona z wyciętym znakiem krzyża na oparciu, w miejscu klasycznego prezbiterium ustawiono krzesła projektu braci Eames. Przeciwwagę stanowią klasyczne żyrandole oraz tradycyjnie pojawiające się we wnętrzach kościelnych dywany. Velcovsky udowadnia, że wiele jeszcze można unowocześnić, jeśli chodzi o wnętrza budowli sakralnych. Jest to dopiero początek zmian, które być może staną się okazją do dalszych badań nie tylko na polu budownictwa kościelnego, ale również dekoracji wnętrz miejsc kultu.

Zaprezentowane przykłady budownictwa sakralnego XX i XXI wieku świadczą o wielkiej zmianie jaka dokonała się w architekturze. Pokazują bowiem zupełnie inny sposób percepcji przekazu wiary, pozbawiony obrazów, dewocjonaliów, a więc tego wszystkiego, do czego architekci i artyści przyzwyczajali wiernych przez zgoła tysiąc lat. Kościół nowoczesny nie stracił jednak nic ze swojej umiejętności oddziaływania na wrażenia i zmysły. Wciąż zachwyca, napawa zdumieniem, zadziwia pięknem, czasem surowością i prostotą.

Ogromna rozmaitość tendencji w architekturze sakralnej świadczy o tym, że architekci wciąż się rozwijają i zmieniają poglądy estetyczne. Nie można oczekiwać, że sztuka w pewnym momencie stanie w miejscu i zakończy swą drogę. Ciągła potrzeba zmian owocuje przewartościowaniem pozornie trwałych prawd. Jednocześnie, mimo przewrotów i rewolucji w dziedzinie architektury sakralnej architekci wciąż przekazują za pomocą swych dzieł doktryny zawarte w Starym i Nowym Testamencie. Przekazy te nie są jednak wyrażone wprost jak to miało miejsce w przypadku obrazów czy rzeźb. Jest to droga trudna, bowiem zawoalowana, symboliczna, dyskretna. Wykorzystanie światła, tak powszechne, a mimo to wciąż zachwycające, przywodzi na myśl wielkie dzieła starożytne. Spuścizna nie została więc odrzucona, jak może się niektórym wydawać. Nowoczesność selektywnie czerpie inspiracje z dorobku kilku tysięcy lat historii sztuki i architektury, tworząc jednocześnie swój niepowtarzalny język wyrazu.

Nowoczesna architektura udowadnia niezbicie, że kościół ma być przede wszystkim miejscem modlitwy, że nie potrzebne są przedmioty, które rozpraszałyby uwagę wiernych. Minął już okres przepychu i bogactwa, złota i brokatów. Wnętrze kościoła staje się na powrót oazą spokoju, gdzie wierni mogą przebywać sam na sam z Bogiem. Jest to zabieg powtarzany w niemal wszystkich nowoczesnych kościołach. Minimalizm, prostota, surowość, asceza. Czy nowy model kościoła przetrwa próbę czasu? Tego nie wiadomo, na pewno jednak pozostanie świadectwem epoki, w jakiej się wykształcił, podobnie jak wszystkie omówione kościoły pozostaną świadectwem nieprzerwanej historii chrześcijaństwa.

${ }^{16} \mathrm{~W}$ Czechach ma również miejsce adaptowanie na szeroką skalę miejsc sakralnych na potrzeby świeckie. Więcej o desakralizacji wnętrz kościelnych pisze w swojej pracy J. Derdowska, Praskie Przemiany, Kraków 2006. 


\title{
PLACES OF WORSHIP MADE OF CONCRETE AND GLASS. THE ORIGINS AND OVERVIEW OF THE MAJOR TRENDS IN THE MODERN CHURCH ARCHITECTURE AFTER THE SECOND WORLD WAR
}

\begin{abstract}
Summary
The modern church architecture appeared together with modernist trends, which were initiated by the two artistic groups- de Stijl and Bauhaus. The art of building they created was very different from what was developed by the previous epochs in the history of art. An early example of modernist church architecture was Robert F. Carr Memorial Chapel of Saint Savior designed in 1952 by Mies van der Rohe. Its simple design was the inspiration for many later buildings, such as the Church of Light designed by Tadao Ando in1988, whose striking formal asceticism set a new quality in the church architecture. Apart from the minimalist trends in church buildings, the artists are inspired by sculpture, which is indicated by such works as the Chapel Ronchamp by Le Corbusiera designed in 1954 or Wotrubakirche from 1976. The architecture current based on natural materials is represented by Alvar Aalto's works -Santa Maria Assunta Church from 1978 and the Church of Christ the Light designed by C.W. Hartman in 2008, whereas Oscar Niemeyer's Brazilian Cathedral from 1970 is an example of the latest technologies in the buildings of glass.

The presented examples of church buildings from the $20^{\text {th }}$ and $21^{\text {st }}$ centuries testify to the great change which took place in the church architecture. These churches show a whole new perspective on the tradition of Christian architecture.
\end{abstract}

